\title{
Steve Sharp
}

Journalism and Conflict in Indonesia: From Reporting Violence to Promoting Peace. New York: Routledge, 2013, xiii + 255 pp. ISBN 9780415531498. Price: EUR 102.50 (hardback).

In the early years of post Soeharto Indonesia, press freedom faced numerous challenges, especially from violent religious conflicts. Journalist faced an uneasy and complicated situation: although the press has been liberated from official censorship, it has been trapped by the dominant interests of media owners.

Sharps's book explains how journalism has responded to such issues. This book is adapted from his $\mathrm{PhD}$ thesis and addresses the key question, 'how does a particular cannon of journalism - news reporting from two influential national dailies, Kompas and Republika - deal with the cultural dimensions of violent conflict during the first two years of the Maluku wars?'

There have been a number of reports, studies, and publications criticizing the role of media in Maluku's violent conflicts, but unusually, this book reports on the complicated Indonesian press situation in post-authoritarianism dealing with violent conflicts. It manages a convincing and wide-ranging analysis. It explores so-called 'primordialism' medias, the 'minimalist reporting model' (which emphasizes profesional certainties of 'factual reporting' and 'neutrality'), identifies common 'professional dilemmas', and exposes the shallow intellectual skills of reporters in understanding 'conflict analysis'. This seven chapter study contributes significantly to understanding Indonesian media studies and violent conflicts.

In addition to introducing the research background and methodology, the first and second chapters discuss theories of communication, journalism, and their relationship to culture. The first two chapters contextualize this book among other media communication studies of violent conflict. The next three chapters offer elaborate explanations of post-New Order Indonesia's media freedom, journalistic culture, and its culture of wars and violence.

(Sub)chapter three discusses the legacy of the Pancasila Press in Indonesia; it departs from the idea of Soepomo's integralistic state and offers an overview of the political context and cultural implications, which explains the dominant military-authoritarian regime at the end of the 1990s. This overview elaborates ideas from the 'perjuangan press' to the Pancasila press, and explores journalistic ideologies. While much of chapter three covers familiar facts, it provides sad evidence of conformity in the newsroom. He discusses editorial control over news and shows that news coverage has been quite biased, despite the professional rhetoric of objectivity. However, he found 'the erosion of professional

(C) HERLAMBANG P. WirATRAMAN, 2014 | DOI: 10.1163/22134379-17001016

This is an open access article distributed under the terms of the Creative Commons 
norms was not only caused by the periodic of the 'strategic ritual' of detached objectivitiy, strategic failures to get access to the site of battle left reporters dependent on the bureaucratic output of government officials, civilian, and military' (p. 77).

Chapter six directly addresses the key research question. It provides an interpretative content analysis of stories in Maluku that were published in the Jakarta dailies, Kompas and Republika from July 1999 to June 2000. Kompas is hyper-dependent on official-state sources, both civilian and military, while Republika apparently relies less on officialdom (p. 161). Using a statistical analysis, the author argues that both papers categorize stories as 'generic and nongeneric descriptors for combatants', 'official state versus partisan sources', and 'Malukan and non-Malukan sources', and concludes that 'religious enmity was presented as natural, inevitable and without end and so lacked explanatory power', and further, that 'by privileging this aspect of religious experience in the news texts, their stories could not begin to decipher the interactions of rogues, warriors and Jakarta-based war beneficiaries that prolonged the war' (p. 174). He convincingly demonstrates that 'the libertarian values—so cherished by journalists - need to be extended to the very people who form the subject matter of reportage' (p. 207). Media freedom depends on meaningful professional ethics, especially in the context of violent conflict, and embracing peace journalism might dramatically shift priorities and challenge assumed values.

This book has succeeded in mapping the causes, actors, and dynamics of violent conflict reportage, and it has contributed ideas and consciousness to change the management of journalists and media. The study is coherent, original, and clear. But it does not provide prescriptions to remedy the situation, which is good and bad. Important questions remain as to the extent the news has been contributing to worsening violent conflict, and the effects of better practices reporters might adopt. And lastly, further research is needed to explore how the violent conflict has been shaped by the dominant medias at the local level.

Herlambang P. Wiratraman

Faculty of Law, Universitas Airlangga

herlambang@fh.unair.ac.id 